\title{
Evaluation of the possibility of tribenuron methyl dose limitation in relations to selected abiotic factors and growth stage of weeds
}

\author{
Ocena możliwości ograniczenia dawki tribenuronu metylu w zależności \\ od wybranych czynników abiotycznych i fazy rozwojowej chwastów
}

\author{
Renata Kieloch*, Mariusz Kucharski
}

\begin{abstract}
Summary
The pot experiment on the possibility of tribenuron methyl dose reduction depending on the interaction of abiotic factors with weed growth stage under controlled conditions was carried out. The effect of the interactions between temperature (20/10 and $10 / 5^{\circ} \mathrm{C}$ ) or relative humidity $(75$ and $50 \%)$ and weeds growth stage (2-4 and 6-8 leaves) was investigated. Tested plants were: Anthemis arvensis L., Papaver rhoeas L. and Stellaria media L. The herbicide was applied at the recommended and reduced doses (15 g a.s./ha and $7.5 \mathrm{~g}$ a.s./ha respectively) alone and in the mixture with adjuvant Trend $90 \mathrm{EC}$. Tribenuron methyl applied without adjuvant at the reduced dose efficiently controlled only $S$. media independently on relative humidity and growth stage of plants. The herbicide used at the reduced dose in the mixture with adjuvant Trend $90 \mathrm{EC}$ was highly efficient against $A$. arvensis, $P$. rhoeas and S. media. Under optimal conditions, i.e. early growth stage and high temperature or relative humidity. Herbicide efficacy was more dependent on growth stage of weeds than on abiotic factor. Herbicide activity was weaker while applied at the reduced dose on older plants, even under higher temperature or relative humidity.
\end{abstract}

Key words: dose of herbicide; Anthemis arvensis L.; Papaver rhoeas L.; Stellaria media L.; temperature; humidity; growth stage

\footnotetext{
Streszczenie rozwojowa

Instytut Uprawy Nawożenia i Gleboznawstwa - Państwowy Instytut Badawczy

Zakład Herbologii i Technik Uprawy Roli

Orzechowa 61, 50-540 Wrocław

*corresponding author: r.kieloch@iung.wroclaw.pl
}

Badania nad możliwością ograniczania dawki tribenuronu metylu w zależności od interakcji czynników abiotycznych z fazą rozwojową chwastów wykonano w komorach klimatycznych. Badano wpływ interakcji temperatury $\left(20 / 10\right.$ i $\left.10 / 5^{\circ} \mathrm{C}\right)$ lub wilgotności powietrza (75 i 50\%) z fazą rozwojową chwastów (2-4 i 6-8 liści). Roślinami testowymi były: Anthemis arvensis L., Papaver rhoeas L. i Stellaria media L. Herbicyd zastosowano w dawce zalecanej (15 g s.cz./ha) i obniżonej (7,5 g s.cz./ha), samodzielnie oraz z dodatkiem adiuwanta Trend 90 EC. Tribenuron metylu aplikowany bez adiuwanta w dawce zredukowanej skutecznie niszczył jedynie $S$. media niezależnie od wilgotności powietrza i fazy rozwojowej roślin. W warunkach optymalnych, tj. faza rozwojowa 2-4 liście i wysoka temperatura $\left(20 / 10^{\circ} \mathrm{C}\right)$ lub wilgotność powietrza $(75 \%)$, herbicyd zastosowany $w$ dawce zredukowanej łącznie $z$ adiuwantem Trend 90 EC był wysoce skuteczny w stosunku do A. arvensis, P. rhoeas i S. media. Skuteczność badanego herbicydu w większym stopniu uzależniona była od fazy rozwojowej chwastów niż czynnika abiotycznego. W przypadku roślin starszych działanie herbicydu w dawce zredukowanej było słabsze, nawet w warunkach wyższej temperatury i wilgotności powietrza.

Słowa kluczowe: dawka herbicydu; Anthemis arvensis L.; Papaver rhoeas L.; Stellaria media L.; temperatura; wilgotność; faza 


\section{Wstęp / Introduction}

Intensywna produkcja roślinna wiąże się niejednokrotnie ze stosowaniem większej ilości herbicydów niż wymaga tego sytuacja na polu. Jednym z założeń obowiązującej obecnie ustawy o integrowanej ochronie roślin jest zminimalizowanie chemicznej ochrony przed agrofagami poprzez m.in. ograniczenie dawek pestycydów (Ustawa 2013). Badania wykazały, że dawki mniejsze niż zaleca producent mogą okazać się na tyle skuteczne, że nawet nie zniszczone całkowicie chwasty są znacząco ograniczone we wzroście, a uratowany plon gwarantuje opłacalność stosowania herbicydu (Piekarczyk 2005; Wesołowski i Cierpiała 2010; Haliniarz 2013). Stosowanie mniejszych dawek herbicydów obwarowane jest wymaganiami odnośnie warunków ich aplikacji. Doniesienia w literaturze podkreślają fakt, że działanie herbicydu w dawce niższej niż zaleca producent jest w większym stopniu uzależnione od przebiegu pogody oraz innych czynników wpływających na skuteczność zabiegu niż środka aplikowanego w dawce zalecanej (Kudsk 2014).

Tribenuron metylu jest substancją czynną (s.cz.) herbicydu zwalczająca chwasty dwuliścienne w roślinach zbożowych. Zgodnie $\mathrm{z}$ zaleceniami, w celu zapewnienia wysokiej skuteczności, herbicydy zawierające tribenuron metylu należy stosować łącznie $\mathrm{z}$ adiuwantami, które wspomagają działanie herbicydów poprzez m.in. wzrost retencji i absorpcji środków, zmniejszenie napięcia powierzchniowego kropel cieczy użytkowej na opryskiwanych powierzchniach (Kierzek i Ratajkiewicz 2004; Wang i Liu 2007; Aliverdi i wsp. 2009).

Efektywność działania herbicydów jest wypadkową szeregu czynników biotycznych, abiotycznych, jak również tych, które są wynikiem świadomych działań człowieka. Stąd też potrzeba oceny ich działania nie tylko pod względem wpływu pojedynczego czynnika, lecz również w odniesieniu do współdziałania dwóch lub większej liczby czynników. Wcześniejsze badania wykazały ograniczenie skuteczności herbicydów stosowanych w niekorzystnych warunkach środowiskowych (Petersen i Hurle 2001; Riethmuller-Haage i wsp. 2007). Uwzględniały one jednak chwasty we wczesnej fazie rozwojowej. Nieznana jest natomiast reakcja chwastów bardziej zaawansowanych w rozwoju na herbicyd stosowany w takich warunkach.

Celem badań była ocena łącznego wpływu czynników abiotycznych i fazy rozwojowej chwastów na efektywność tribenuronu metylu stosowanego w dawce zredukowanej. Badano również przydatność adiuwanta $\mathrm{w}$ łącznej aplikacji z herbicydem w zależności od współdziałania powyższych czynników.

\section{Materiały i metody / Materials and methods}

Doświadczenia przeprowadzono w komorach klimatycznych. Założono je w układzie kompletnej randomizacji w trzech powtórzeniach. W ramach prac oceniano skuteczność tribenuronu metylu stosowanego w dawce zalecanej i obniżonej o połowę, w zróżnicowanych warunkach środowiskowych i w różnej fazie rozwojowej chwastów.
Badania obejmowały dwa rodzaje doświadczeń, w których testowano wpływ następujących kombinacji na działanie herbicydu:

1. temperatura powietrza $\times$ faza rozwojowa chwastów $-20^{\circ} \mathrm{C}$ w dzień i $10^{\circ} \mathrm{C}$ w nocy $\left(20 / 10^{\circ} \mathrm{C}\right) \times$ faza $2-4$ liści

$-20^{\circ} \mathrm{C}$ w dzień i $10^{\circ} \mathrm{C}$ w nocy $\left(20 / 10^{\circ} \mathrm{C}\right) \times$ faza $6-8$ liści

$-10^{\circ} \mathrm{C}$ w dzień i $5^{\circ} \mathrm{C}$ w nocy $\left(10 / 5^{\circ} \mathrm{C}\right) \times$ faza $2-4$ liści

$-10^{\circ} \mathrm{C}$ w dzień i $5^{\circ} \mathrm{C}$ w nocy $\left(10 / 5^{\circ} \mathrm{C}\right) \times$ faza $6-8$ liści

2. wilgotność powietrza $\times$ faza rozwojowa chwastów

$-75 \% \times$ faza $2-4$ liści

$-75 \% \times$ faza $6-8$ liści

$-50 \% \times$ faza $2-4$ liści

$-50 \% \times$ faza $6-8$ liści.

Nasiona chwastów (Anthemis arvensis L., Papaver rhoeas L. i Stellaria media L.) wysiano do doniczek o średnicy $8 \mathrm{~cm}$ wypełnionych podłożem składającym się $\mathrm{z}$ torfu i piasku wymieszanych $\mathrm{w}$ stosunku objętościowym 2:1, na głębokość $0,5 \mathrm{~cm}$. Wysiewano je w odstępie tygodniowym, aby w momencie aplikacji herbicydów uzyskać rośliny będące $\mathrm{w}$ dwóch zróżnicowanych fazach rozwojowych: 2-4 i 6-8 liści. W doświadczeniu nad wpływem interakcji temperatury i fazy rozwojowej chwastów doniczki umieszczono w komorach klimatycznych, w których utrzymywano temperaturę na poziomie $20^{\circ} \mathrm{C}$ w dzień i $10^{\circ} \mathrm{C}$ w nocy. Dzień przed planowanym zabiegiem temperaturę $\mathrm{w}$ komorach klimatycznych dostosowano do badanych poziomów, tj. $20 / 10^{\circ} \mathrm{C}$ i $10 / 5^{\circ} \mathrm{C}$. Wilgotność powietrza oraz intensywność światła były takie same dla badanych poziomów temperatury i wynosiły odpowiednio $70 \%$ oraz $10000 \mathrm{~lx}$. W doświadczeniu oceniającym wpływ interakcji wilgotność powietrza/faza rozwojowa chwastów uwzględniono dwa poziomy wilgotności powietrza: 75 i 50\%, natomiast temperatura wynosiła $20 / 10^{\circ} \mathrm{C}$ dla obu poziomów wilgotności. Fotoperiod w obu doświadczeniach wynosił 14 godzin dnia i 10 godzin nocy.

Tribenuron metylu zastosowano $\mathrm{w}$ formie herbicydu Granstar 75 WG w dawce podstawowej 15 g s.cz./ha i obniżonej o połowę 7,5 g s.cz./ha. Herbicyd aplikowano samodzielnie oraz łącznie $\mathrm{z}$ adiuwantem Trend $90 \mathrm{EC}$. Dzień przed planowanym opryskiwaniem wykonano przerywkę, zostawiając po 4 rośliny w każdej z doniczek. Aplikację herbicydów przeprowadzono w komorze opryskowej z ruchomą dyszą (TeeJet XR 11003-VS) pod ciśnieniem $200 \mathrm{kPa}$ i przy wydatku cieczy użytkowej 250 1/ha. Po upływie trzech tygodni od zabiegu przeprowadzono zbiór roślin, a następnie określono świeżą masę części nadziemnych chwastów.

$\mathrm{Na}$ obiektach traktowanych herbicydami, na podstawie ubytku świeżej masy chwastów pod wpływem działania stosowanych środków określono ich skuteczność, którą wyrażono w procentach względem obiektu kontrolnego. Obliczenia statystyczne wykonano na wyżej wymienionych wartościach zniszczenia chwastów uprzednio przekształconych według wzoru Blissa. Obliczenia przeprowadzono dla układu dwuczynnikowego, gdzie jednym z czynników była kombinacja czynnik abiotyczny $\times$ faza rozwojowa, natomiast drugim czynnikiem była dawka herbicydu. 


\section{Wyniki i dyskusja / Results and discussion}

Herbicyd Granstar 75 WG stosowany samodzielnie nie niszczył skutecznie $A$. arvensis bez względu na temperaturę powietrza oraz fazę rozwojową roślin (tab. 1). W przypadku chwastów w fazie 2-4 liści, rosnących zarówno w warunkach wyższych $\left(20 / 10^{\circ} \mathrm{C}\right)$, jak i niższych temperatur $\left(10 / 5^{\circ} \mathrm{C}\right)$, dodatek adiuwanta Trend 90 EC skutkował wysokim efektem chwastobójczym środka stosowanego w dawce zalecanej, jak i obniżonej. Podobne rezultaty uzyskano dla aplikacji dawki podstawowej w stosunku do roślin bardziej wyrośniętych (6-8 liści) rosnących w warunkach cieplejszych. Zabieg wykonany w niższych temperaturach, w fazie 6-8 liści chwastów, skutkował słabszym efektem chwastobójczym wynoszącym odpowiednio 79 i $82 \%$ dla dawki zredukowanej i podstawowej. Rośliny P. rhoeas były skutecznie niszczone przez herbicyd Granstar 75 WG aplikowany samodzielnie, jedynie w warunkach optymalnych dla działania środka (faza rozwojowa 2-4 liści i wyższa temperatura powietrza) i tylko przez dawkę zalecaną (tab. 1). Badany środek aplikowany $\mathrm{w}$ dawce zalecanej $\mathrm{z}$ dodatkiem adiuwanta Trend 90 EC skutecznie niszczył powyższy gatunek, niezależnie od temperatury powietrza oraz fazy rozwojowej roślin, natomiast dawka zredukowana okazała się wysoce efektywna jedynie w warunkach optymalnych. Aplikacja środka $w$ dawce obniżonej na rośliny $w$ fazie 6-8 liści, jak również rosnące $\mathrm{w}$ niższych temperaturach (bez względu na fazę rozwojową) skutkowała znisz- czeniem chwastów w granicach $83-85 \%$. Rośliny S. media rosnące w temperaturze $20 / 10^{\circ} \mathrm{C}$ były efektywnie redukowane przez obie dawki herbicydu Granstar 75 WG stosowanego samodzielnie oraz $\mathrm{z}$ adiuwantem, bez względu na fazę rozwojową roślin (tab. 1). Równie wysoką skuteczność uzyskano po aplikacji środka na rośliny we wczesnej fazie rozwojowej rosnące $\mathrm{w}$ temperaturze $10 / 5^{\circ} \mathrm{C}$. Spadek efektywności do poziomu średniego (80\%) nastąpił po zastosowaniu dawki obniżonej $\mathrm{w}$ warunkach niższych temperatur, w przypadku roślin w fazie 6-8 liści.

Tribenuron metylu zastosowany samodzielnie, $\mathrm{w}$ obu dawkach, efektywnie redukował $A$. arvensis jedynie w warunkach wyższej wilgotności powietrza i gdy zabieg wykonano w fazie 2-4 liści roślin (tab. 2). W przypadku łącznej aplikacji herbicydu $\mathrm{w}$ dawce zalecanej $\mathrm{z}$ adiuwantem bardzo dobre zniszczenie $A$. arvensis osiągnięto dla wszystkich kombinacji wilgotność powietrza $\times$ faza rozwojowa. Dawka zredukowana okazała się wysoce efektywna, jedynie gdy zabieg wykonano na rośliny we wczesnej fazie rozwojowej, bez względu na wilgotność powietrza. Samodzielna aplikacja herbicydu Granstar 75 WG okazała się skuteczna w zwalczaniu $P$. rhoeas jedynie w optymalnych warunkach i gdy do zabiegu użyto zalecaną dawkę środka (tab. 2). W pozostałych warunkach środek zastosowany samodzielnie wykazał słabe działanie na chwasty, nawet gdy zastosowano go w dawce pełnej. Łączna aplikacja herbicydu (w dawce podstawowej oraz obniżonej) $\mathrm{z}$ adiuwantem skutkowała bardzo dobrym zwalczaniem roślin $P$. rhoeas w fazie 2-4 liści, na obu

Tabela 1. Skuteczność tribenuronu metylu stosowanego samodzielnie oraz z adiuwantem w zależności od temperatury i fazy rozwojowej chwastów [\%]

Table 1. The efficacy of tribenuron methyl applied alone and with adjuvant according to the temperature and growth stage of weeds [\%]

\begin{tabular}{|c|c|c|c|c|c|}
\hline \multirow{3}{*}{$\begin{array}{l}\text { Herbicyd } \\
\text { Herbicide }\end{array}$} & \multirow{3}{*}{$\begin{array}{l}\text { Dawka } \\
\text { Dose }\end{array}$} & \multicolumn{4}{|c|}{ Temperatura - Temperature } \\
\hline & & \multicolumn{2}{|c|}{$20 / 10^{\circ} \mathrm{C}$} & \multicolumn{2}{|c|}{$10 / 5^{\circ} \mathrm{C}$} \\
\hline & & $\begin{array}{c}\text { faza } 2-4 \text { liści } \\
\text { stage } \\
\text { of } 2-4 \text { leaves }\end{array}$ & $\begin{array}{c}\text { faza } 6-8 \text { liści } \\
\text { stage } \\
\text { of } 6-8 \text { leaves }\end{array}$ & $\begin{array}{c}\text { faza } 2-4 \text { liści } \\
\text { stage } \\
\text { of } 2-4 \text { leaves }\end{array}$ & $\begin{array}{c}\text { faza } 6-8 \text { liści } \\
\text { stage } \\
\text { of } 6-8 \text { leaves }\end{array}$ \\
\hline \multicolumn{6}{|c|}{ Anthemis arvensis L. } \\
\hline \multirow{2}{*}{ Tribenuron methyl } & $20 \mathrm{~g} / \mathrm{ha}$ & $83 \mathrm{~b}$ & $77 \mathrm{c}$ & $83 \mathrm{~b}$ & $75 \mathrm{c}$ \\
\hline & $10 \mathrm{~g} / \mathrm{ha}$ & $81 \mathrm{~b}$ & $61 \mathrm{~d}$ & $68 \mathrm{~d}$ & $62 \mathrm{~d}$ \\
\hline \multirow{2}{*}{$\begin{array}{l}\text { Tribenuron methyl + } \\
\text { Trend } 90 \text { EC }\end{array}$} & $20 \mathrm{~g} / \mathrm{ha}+0,05 \%$ & $94 \mathrm{a}$ & $89 \mathrm{a}$ & $88 \mathrm{a}$ & $82 \mathrm{~b}$ \\
\hline & $10 \mathrm{~g} / \mathrm{ha}+0,05 \%$ & $89 \mathrm{a}$ & $78 \mathrm{~b}$ & $86 \mathrm{ab}$ & $79 \mathrm{~b}$ \\
\hline \multicolumn{6}{|c|}{ Papaver rhoeas L. } \\
\hline \multirow{2}{*}{ Tribenuron methyl } & $20 \mathrm{~g} / \mathrm{ha}$ & 99 a & $72 \mathrm{c}$ & $62 \mathrm{~d}$ & $59 \mathrm{e}$ \\
\hline & $10 \mathrm{~g} / \mathrm{ha}$ & $80 \mathrm{c}$ & $67 \mathrm{~d}$ & $54 \mathrm{e}$ & $49 \mathrm{e}$ \\
\hline \multirow{2}{*}{$\begin{array}{l}\text { Tribenuron methyl + } \\
\text { Trend } 90 \text { EC }\end{array}$} & $20 \mathrm{~g} / \mathrm{ha}+0,05 \%$ & $100 \mathrm{a}$ & $93 \mathrm{a}$ & $92 \mathrm{a}$ & $90 \mathrm{~b}$ \\
\hline & $10 \mathrm{~g} / \mathrm{ha}+0,05 \%$ & $99 \mathrm{a}$ & $83 \mathrm{~b}$ & $85 \mathrm{~b}$ & $83 \mathrm{~b}$ \\
\hline \multicolumn{6}{|c|}{ Stellaria media $\mathrm{L}}$. \\
\hline \multirow{2}{*}{ Tribenuron methyl } & $20 \mathrm{~g} / \mathrm{ha}$ & $98 \mathrm{a}$ & $97 \mathrm{a}$ & $95 \mathrm{a}$ & $84 \mathrm{~b}$ \\
\hline & $10 \mathrm{~g} / \mathrm{ha}$ & $98 \mathrm{a}$ & $97 \mathrm{a}$ & $94 \mathrm{a}$ & $79 \mathrm{~b}$ \\
\hline \multirow{2}{*}{$\begin{array}{l}\text { Tribenuron methyl + } \\
\text { Trend } 90 \text { EC }\end{array}$} & $20 \mathrm{~g} / \mathrm{ha}+0,05 \%$ & $99 \mathrm{a}$ & $98 \mathrm{a}$ & $96 \mathrm{a}$ & $87 \mathrm{a}$ \\
\hline & $10 \mathrm{~g} / \mathrm{ha}+0,05 \%$ & $99 \mathrm{a}$ & $97 \mathrm{a}$ & $94 \mathrm{a}$ & $80 \mathrm{~b}$ \\
\hline
\end{tabular}

Wartości oznaczone tą samą literą nie różnią się istotnie w obrębie gatunku

Values marked by the same letter do not differ significantly within species 
Tabela 2. Skuteczność tribenuronu metylu stosowanego samodzielnie oraz z adiuwantem w zależności od wilgotności powietrza i fazy rozwojowej chwastów [\%]

Table 2. The efficacy of tribenuron methyl applied alone and with adjuvant according to the relative humidity and growth stage of weeds $[\%]$

\begin{tabular}{|c|c|c|c|c|c|}
\hline \multirow{3}{*}{$\begin{array}{l}\text { Herbicyd } \\
\text { Herbicide }\end{array}$} & \multirow{3}{*}{$\begin{array}{l}\text { Dawka } \\
\text { Dose }\end{array}$} & \multicolumn{4}{|c|}{ Wilgotność - Humidity } \\
\hline & & \multicolumn{2}{|c|}{$75 \%$} & \multicolumn{2}{|c|}{$50 \%$} \\
\hline & & $\begin{array}{c}\text { faza } 2-4 \text { liści } \\
\text { stage } \\
\text { of } 2-4 \text { leaves }\end{array}$ & $\begin{array}{c}\text { faza } 6-8 \text { liści } \\
\text { stage } \\
\text { of } 6-8 \text { leaves }\end{array}$ & $\begin{array}{c}\text { faza } 2-4 \text { liści } \\
\text { stage } \\
\text { of } 2-4 \text { leaves }\end{array}$ & $\begin{array}{c}\text { faza } 6-8 \text { liści } \\
\text { stage } \\
\text { of } 6-8 \text { leaves }\end{array}$ \\
\hline \multicolumn{6}{|c|}{ Anthemis arvensis L. } \\
\hline \multirow{2}{*}{ Tribenuron methyl } & $20 \mathrm{~g} / \mathrm{ha}$ & $90 \mathrm{a}$ & $71 \mathrm{c}$ & $75 \mathrm{~b}$ & $69 \mathrm{c}$ \\
\hline & $10 \mathrm{~g} / \mathrm{ha}$ & $86 \mathrm{~b}$ & $59 \mathrm{~d}$ & $61 \mathrm{c}$ & $58 \mathrm{~d}$ \\
\hline \multirow{2}{*}{$\begin{array}{l}\text { Tribenuron methyl + } \\
\text { Trend } 90 \text { EC }\end{array}$} & $20 \mathrm{~g} / \mathrm{ha}+0,05 \%$ & $99 \mathrm{a}$ & $86 \mathrm{~b}$ & $99 \mathrm{a}$ & $86 \mathrm{~b}$ \\
\hline & $10 \mathrm{~g} / \mathrm{ha}+0,05 \%$ & $98 \mathrm{a}$ & $79 \mathrm{~b}$ & $97 \mathrm{a}$ & $76 \mathrm{~b}$ \\
\hline \multicolumn{6}{|c|}{ Papaver rhoeas L. } \\
\hline \multirow{2}{*}{ Tribenuron methyl } & $20 \mathrm{~g} / \mathrm{ha}$ & $88 \mathrm{~b}$ & $53 \mathrm{c}$ & $59 \mathrm{c}$ & $55 \mathrm{c}$ \\
\hline & $10 \mathrm{~g} / \mathrm{ha}$ & $79 \mathrm{~b}$ & $43 \mathrm{~d}$ & $49 \mathrm{~d}$ & $46 \mathrm{~d}$ \\
\hline \multirow{2}{*}{$\begin{array}{l}\text { Tribenuron methyl + } \\
\text { Trend } 90 \text { EC }\end{array}$} & $20 \mathrm{~g} / \mathrm{ha}+0,05 \%$ & $98 \mathrm{a}$ & $97 \mathrm{a}$ & $98 \mathrm{a}$ & 94 a \\
\hline & $10 \mathrm{~g} / \mathrm{ha}+0,05 \%$ & $96 \mathrm{a}$ & $82 \mathrm{~b}$ & $97 \mathrm{a}$ & $80 \mathrm{~b}$ \\
\hline \multicolumn{6}{|c|}{ Stellaria media L. } \\
\hline \multirow{2}{*}{ Tribenuron methyl } & $20 \mathrm{~g} / \mathrm{ha}$ & $100 \mathrm{a}$ & $93 \mathrm{a}$ & $99 \mathrm{a}$ & $90 \mathrm{a}$ \\
\hline & $10 \mathrm{~g} / \mathrm{ha}$ & 99 a & $91 \mathrm{a}$ & $98 \mathrm{a}$ & $87 \mathrm{~b}$ \\
\hline \multirow{2}{*}{$\begin{array}{l}\text { Tribenuron methyl + } \\
\text { Trend } 90 \text { EC }\end{array}$} & $20 \mathrm{~g} / \mathrm{ha}+0,05 \%$ & $100 \mathrm{a}$ & 97 a & 99 a & $92 \mathrm{a}$ \\
\hline & $10 \mathrm{~g} / \mathrm{ha}+0,05 \%$ & $100 \mathrm{a}$ & 96 a & $99 \mathrm{a}$ & $90 \mathrm{a}$ \\
\hline
\end{tabular}

Wartości oznaczone tą samą literą nie różnią się istotnie w obrębie gatunku

Values marked by the same letter do not differ significantly within species

poziomach wilgotności powietrza. W przypadku zabiegu wykonanego na chwasty bardziej zaawansowane w rozwoju, na obu poziomach wilgotności powietrza, wysoki efekt chwastobójczy osiągnięto jedynie dla herbicydu stosowanego w dawce podstawowej. Rośliny $S$. media były skutecznie zwalczane przez herbicyd Granstar 75 WG aplikowany zarówno w dawce zalecanej, jak i obniżonej, samodzielnie i $\mathrm{z}$ dodatkiem adiuwantów bez względu na wilgotność powietrza oraz fazę rozwojową chwastów (tab. 2). W warunkach najmniej korzystnych dla działania herbicydu, tj. niska wilgotność powietrza i zaawansowana faza rozwojowa chwastów, zaobserwowano istotne statystycznie różnice w skuteczności obu dawek środka stosowanego samodzielnie.

Zgodnie $\mathrm{z}$ zaleceniami producenta, tribenuron metylu (herbicyd Granstar 75 WG) wykazuje wysoką skuteczność, gdy stosuje się go łącznie z adiuwantem. Przeprowadzone badania wykazały jednak, że środek ten stosowany samodzielnie może skutecznie niszczyć $A$. arvensis i $P$. rhoeas, gdy warunki aplikacji są optymalne, tj. sprzyjająca działaniu herbicydu temperatura i wilgotność powietrza oraz wczesna faza rozwojowa (2-4 liście) chwastów. Należy podkreślić fakt, że w przypadku samodzielnego zastosowania herbicydu dawka obniżona wykazała znacznie słabsze działanie. Podobne rezultaty uzyskano w przypadku tribenuronu metylu stosowanego na różnych typach gleb oraz na rośliny o różnym stanie uwilgotnienia (Kieloch 2013). Z kolei Stagnari i wsp. (2007) wykazali, że dla osiągnięcia skutecznej redukcji roślin $P$. rhoeas dawkę tribenuronu metylu aplikowanego bez dodatku adiuwanta można obniżyć o $25 \%$. Spośród ocenianych gatunków chwastów odmienną reakcją odznaczała się S. media, która okazała się wrażliwa na obie dawki herbicydu aplikowanego samodzielnie oraz łącznie $\mathrm{z}$ adiuwantem, w porównywanych warunkach wilgotnościowych oraz w badanych fazach rozwojowych. Wynika to z wysokiej wrodzonej wrażliwości tego gatunku na niektóre substancje czynne herbicydów. We wcześniejszych badaniach własnych również wykazano, że stopień zwalczenia $S$. media był w niewielkim stopniu zależny od czynników klimatycznych i fazy rozwojowej roślin, jak również od dawki herbicydów (Kieloch i Domaradzki 2011; Kieloch i wsp. 2013). W przypadku pozostałych gatunków chwastów, dodatek adiuwanta znacząco poprawił efektywność herbicydu, co umożliwiło jego aplikację w warunkach mniej sprzyjających jego działaniu oraz obniżenie dawki środka. Adiuwanty odgrywają znaczącą rolę w niwelowaniu niekorzystnego wpływu warunków środowiska na efektywność herbicydów, jak również ich dodatek umożliwia znaczne ograniczenie dawki herbicydu, z jednoczesnym zachowaniem skuteczności chwastobójczej na satysfakcjonujacym poziomie (Stagnari i wsp. 2007; Javaid i wsp. 2012).

$\mathrm{Na}$ końcowy rezultat działania herbicydu wpływa szereg czynników, spośród których wiodącą rolę odgrywają warunki siedliskowe oraz faza rozwojowa chwastów (Zargar i wsp. 2011; Matzenbacher i wsp. 2014). Na podstawie przeprowadzonych badań wykazano, że tribe- 
nuron metylu stosowany łącznie $\mathrm{z}$ adiuwantem $\mathrm{w}$ zalecanej dawce, w większości przypadków skutecznie niszczył chwasty niezależnie od czynnika abiotycznego oraz fazy rozwojowej chwastów. Obniżenie dawki herbicydu, nawet gdy aplikowany był w optymalnych warunkach wilgotności i temperatury powietrza, lecz na rośliny bardziej zaawansowane w rozwoju, skutkowało znacznie słabszym zniszczeniem chwastów. Może to wskazywać na bardziej znaczącą rolę fazy rozwojowej w kształtowaniu efektu chwastobójczego herbicydu niż warunków klimatycznych.

\section{Wnioski / Conclusions}

1. Tribenuron metylu aplikowany bez adiuwanta $w$ dawce zredukowanej o $50 \%$ skutecznie niszczył jedynie $S$. media, niezależnie od fazy rozwojowej roślin i wilgotności powietrza.
2. W warunkach optymalnych, tj. wczesna faza rozwojowa chwastów oraz wyższa temperatura lub wilgotność powietrza, tribenuron metylu stosowany łącznie $\mathrm{z}$ adiuwantem Trend $90 \mathrm{EC} \mathrm{w}$ dawce obniżonej o 50\% był skuteczny w stosunku do $A$. arvensis, $P$. rhoeas i $S$. media.

3. Skuteczność badanego herbicydu w większym stopniu uzależniona była od fazy rozwojowej chwastów niż czynnika abiotycznego. W przypadku roślin starszych działanie herbicydu w dawce zredukowanej było słabsze, nawet w warunkach optymalnej temperatury i wilgotności powietrza.

Opracowanie wykonano w ramach zadania $2.6 \mathrm{w}$ programie wieloletnim Instytutu Uprawy Nawożenia i Gleboznawstwa - Państwowego Instytutu Badawczego pt. „Wspieranie działań w zakresie kształtowania środowiska rolniczego i zrównoważonego rozwoju produkcji rolniczej w Polsce" realizowanym w latach 2011-2015.

\section{Literatura / References}

Aliverdi A., Mohassel M.H.R., Mahallati M.N. 2009. Increased foliar activity of clodinafop-propargyl and/or tribenuron-methyl by surfactants and their synergistic action on wild oat (Avena ludoviciana) and wild mustard (Sinapis arvensis). Weed Biology and Management 9 (4): 292-299.

Haliniarz M. 2013. Skuteczność zwalczania chwastów w pszenicy ozimej w zależności od dawki chlorotoluronu (Lentipur Flo 500 SC). Annales Universitatis Mariae Curie-Skłodowska, Sectio E, LXIX (3): 20-31.

Javaid M.M., Tanveer A., Ahmad R., Yaseen M., Khaliq A. 2012. Optimizing activity of herbicides at reduced rate on Emex spinosa Campd. with adjuvants. Planta Daninha 30 (2): 425-435.

Kieloch R. 2013. Wpływ niektórych warunków klimatycznych i glebowych na działanie tribenuronu metylu w zależności od wysokości dawki i sposobu aplikacji. [Influence of some climate and soil conditions on tribenuron methyl activity depending on herbicide rate and application method]. Progress in Plant Protection/Postępy w Ochronie Roślin 54 (1): 38-43.

Kieloch R., Domaradzki K. 2011. The role of the growth stage of weeds in their response to reduced herbicide doses. Acta Agrobotanica 64 (4): 259-266.

Kieloch R., Sadowski J., Domaradzki K. 2013. Amino acids content and biomass productivity of selected weed species as an indicator of their response to herbicide stress. Acta Agrobotanica 66 (3): 81-88.

Kierzek R., Ratajkiewicz H. 2004. Wpływ adiuwantów i parametrów opryskiwania na retencję cieczy na liściach w wybranych roślinach jednoliściennych. [Effect of adjuvants and spray parameters on retention of liquids on selected monocotyledone foliage]. Progress in Plant Protection/Postępy w Ochronie Roślin 44 (2): 828-831.

Kudsk P. 2014. Reduced herbicide rates: present and future. Proceedings of 26th German Conference on Weed Biology and Weed Control. Germany, Braunschweig, 11-13 March, 2014. Julius-Kühn-Archiv 443: 37-44. DOI: http://dx.doi.org/10.5073/jka. 2014.443.003

Matzenbacher F.O., Vidal R.A., Merotto Jr. A., Trezzi M.M. 2014. Environmental and physiological factors that affect the efficacy of herbicides that inhibit the enzyme photoporphyrinogen. Planta Daninha 32 (2): 457-463.

Petersen J., Hurle K. 2001. Influence of climatic conditions and plant physiology on glufosinate-ammonium efficacy. Weed Research 41 (1): 31-39.

Piekarczyk M. 2005. Możliwość redukcji dawek herbicydów Aminopielik Super 464 SL i Chisel 75 WG w odchwaszczaniu jęczmienia jarego. Acta Scientarum Polonorum, Agricultura 4 (1): 89-95.

Riethmuller-Haage I., Bastiaans L., Kempenaar C., Smutny V., Kropff M.J. 2007. Are pre-spraying growing conditions a major determinant of herbicide efficacy? Weed Research 47 (5): 415-424.

Stagnari F., Chiarini M., Pisante M. 2007. Influence of fluorinated surfactants on the efficacy of some post-emergence sulfonylurea herbicides. Journal of Pesticide Science 32 (1): 16-23.

Ustawa z dnia 8 marca 2013 r. o środkach ochrony roślin (Dz.U. 2013 poz. 455).

Wang C.J., Liu Z.Q. 2007. Foliar uptake of pesticides - Present status and future challenge. Pesticide Biochemistry and Physiology 87 (1): $1-8$

Wesołowski M., Cierpiała R. 2010. Plonowanie i zachwaszczenie pszenicy ozimej w zależności od dawek herbicydu Huzar 05 WG. Acta Agrophysica 15 (2): 429-439.

Zargar M., Mafakheri S., Rostami R. 2011. Weeds response to application times and doses of herbicide in different red bean cultivars. Annals of Biological Research 2 (6): 624-629. 